\title{
The construction of welfare among elders: a religious perspective
}

\begin{abstract}
The article shows how elderly people build their well-being through their religious beliefs and practices, focusing on the most frequent problems and needs. The research focuses on: health and strength, in the supply of their needs, in the sense and meaning and in security and hope, as the most felt demands that older adults have. It is based on the fact that older people state that they have a greater attachment to their religious beliefs and practices and this leads to building and expressing feelings of well-being regardless of their situation. It concludes by saying that well-being in old age is not derived from the biological, economic and social aspects, but in the possibility of believing in a God, creator of everything that exists.
\end{abstract}

Volume 3 Issue 3 - 2018

\section{Felipe R Vázquez Palacios}

Researcher, Center for Research and Higher Studies in Social Anthropology, Mexico

\begin{abstract}
Correspondence: Felipe R Vázquez Palacios, Researcher, Center for Research and Higher Studies in Social Anthropology, Mexico, Tel +52 228842 3940, Email fevaz19@gmail.com
\end{abstract}

Received: December 01, 2017 | Published: May 21, 2018

Keywords: welfare, religious practices and beliefs, older adults

\section{Introduction}

The guiding question of the present paper is: How elders construct their welfare through their religious practices and beliefs, especially given the complexity of their problems and their most recurrent needs? ${ }^{1}, 1$ On the basis of my fieldwork, I discuss four aspects in which religious experience more strongly impact on elders' welfare.
a. Health and strength
b. Meeting their needs
c. Sense and meaning
d. Safety and hope

As social scientists, we only occasionally articulate the whole narrative of religious experience. We usually listen to their stories (narratives), describe their conversion, pay attention to how they

\footnotetext{
${ }^{1}$ It is important to keep in mind that the human being is essentially religious -as compared to becoming a citizen or political rights subject. As made evident by the INEGI census, practices and religious beliefs are deeply rooted in our country. The 2010 national census shows that $92.60 \%$ of the population practices a religion, while only $4.68 \%$ reports no to be ascribed to any religion. According to these data, it is important to mention that $82.72 \%$ are catholic, and only $9.88 \%$ professes a different religion. ${ }^{1}$ attending to the distribution of the population by sex according to religious preferences, we find a growing impact of beliefs and religious practices on the life of people over 50 years old, especially on women. To believe in God, as attested by our data base, was more consistent among elderly women than among elderly men $(100 \%$ vs $97 \%$ ). Attendance to church was still more reveling, that is, $97 \%$ of women attend to church unless once in a week, while only $80 \%$ of men do so -and not very often, by the way-, usually when special events or celebrations take place. Elder women and men stand out as having more solid criteria regarding their beliefs and practices; it is them who support more broadly the reason of their beliefs; who Incorporate, to a larger extent, the religious content into their daily life as mediated by worldviews and expressed through rationalizations, beliefs and accounts of their closest reality.
}

meet or solve their needs -many of them linked to miracles-, but we fail to connect these aspects with the symbolic and divine levels, and the transcendence they have in their lives. We tend to view these experiences as part of our consultants' private life, and it is not our concern as social scientists to go beyond, but rather to neutralize them or leave aside their true and helpful character for every believer. All this is usually omitted, because it is seen as inaccessible or irrelevant to anthropological analysis. We make anthropology of the word, but we do not make anthropology of the word related to an action and what it involves for the believer's life. ${ }^{2}$ By virtue of the socioeconomic and health situation of most elder people, we might think that they are the age group more vulnerable as to their welfare, ${ }^{2-4}$ given that the older they become, the lower their income and the higher the risk of chronicle disease and/or accidents. However, the socioeconomic and health factors do not completely account for welfare. There are other variables, which elder refer to consistently, such as social benefits, company, control, autonomy, self-realization, pleasure, love, and fullness among others which has been included by contemporary scholars as part of the variable happiness, as life's major aim.

\section{Development of the topic}

My starting point is that oldest people show to keep a stronger link to their religious practices and beliefs, ${ }^{3},{ }^{4}$ which drives to the

${ }^{2}$ Believing and faith do not mean that things actually happen, but they allow to creating expectations on the basis of the divine action. Faith guides action and can be either favorable or not. In case it is, it contributes to consolidate our faith; if not so, it strengths it, too, because it is preferable to believe than not believe.

${ }^{3}$ Although it is true that traditional religious seem to decline in our contemporary societies, there is an increasing tendency of people to highlight the importance of "spirituality" in their lives. Spirituality seems to migrate from a collective dimension to a more individual and subjective one, which does not need a formal structure of doctrinal beliefs or a community nucleus.

${ }^{4}$ McFadden (1995) makes evident the elders' higher level of religious commitment and frequency of participation in religious activities as compared with younger people, given that health, economic and social problems are 
construction and expression of a higher sense of welfare, regardless of their situation, since these religious practices help them to endure aging as a construction that interweaves daily, natural and divine elements. All of them are expressed through a gamut of objective and subjective experiences, which penetrate the ways and styles of life, providing the existence with sense and meaning. I view the religious practices and beliefs as a symbolic capital sustained on the faith in God, which involves consistent effort and practices, as well as the knowledge of collective experience alluded by biblical passages, testimony and other's religious experience of similar or even worse conditions and found an answer to why and what for to live; in addition to maintain a sense of consolation, security, advise, health, and fulfillment, as they knew supported or protected by God. Elders refer four aspects in which religious experience exert a stronger impact on the construction of welfare: ${ }^{5,5}$

I. Health and force, which go beyond of the lack of disease and physical welfare. With regard to force, it is not only physical in nature, but volitional, so that makes possible to overcome addictions, negative attitudes, temptations, in other words the strength that makes possible to defeat the vicissitude of life. Strength and health are involved in the term: "a full, abundant life".

II. The provisioning of their needs, which are not only material and/or economic in character, but also socio-cultural, spiritual and valuesrelated.

III. The sense and meaning of life, where they find a guidance that provides life with structure and coherence, organizing and providing existential sense, as well as transcendence.

IV. The security and hopes, in a complicated and violent world, and also in a stage of life in which it is hard to keep alright, it is indispensable to relay and trust in something or someone that can give protection, and is on our side.

According to our information, these four aspects constitute the nucleus where the elder's welfare resides. Their physical, economic, spiritual, and family welfare, as well as be good about themselves. Let us look at some examples and the way welfare is constructed. I understand welfare not only meeting basic needs, but basically the preservation of capabilities and functions, rather than owning goods and resources and the ways they take advantage of them; as well as the pleasure experienced in the form of feelings, emotions (human and religious) and mood, among others. Qualitative research demonstrates that religion encourage retrospective reflection in order to reconstruct life, fostering expectations on the guise of hope based on the belief of divine agency. To the extent that his/her age progresses, according to our consultants, "everyday things" (to feed, to wear, to keep clean, economical responsibility, to keep house, to take care of their family members) is reinterpreted and lived in different ways, and especially

more frequent. He investigates in depth how elder construct their personal meanings and how they integrate religious practices and beliefs to their lives. It is helpful to add that only $50 \%$ of those, who do not attend to religious activities, especially people over 75 years old, exhibit physical disability or health problems that make difficult their participation.

${ }^{5}$ Elison,6 studies the religious involvement and its influence on welfare of adult people. He finds four major forms of incidence: 1) through social integration and support; 2) through the establishment of personal and divine relationships; 3 ) through the assignment of meaning systems and existential coherence, and 4) through the promotion of religious organizational patterns more specific to their personal life styles. when they are in touch with religious practices and beliefs, given that elder believers construct their expectations while thinking in the divine action, providing themselves with meanings and experiences that generate welfare. ${ }^{6}$ Let us make evident, by appealing to Juana's (ninety nine years old, catholic) testimony, what has been discussed above. She told me: "Earlier, I liked to go out, to walk looking at shops; now I feel afraid of; if I go out it is only to the church and always accompanied. Once being there I forget all my aches and pains.

Some years ago, I disliked that somebody break a dish, a cup, or that something was lost, now I don't care any longer. Those things I used to enjoy have lost their charm. Now what it is really important is to have the little virgin, to pray rosary to beg God for protection and health, and that they allow me to hear my radio. It doesn't care either that they laughed at me or think I'm crazy, which it bothered me then. Now, it does not care at all. God fills me with love to forgive anybody which offends me". Religious practices and beliefs can provide elders with welfare, with motivation, relaxation, consolation and resignation before the unavoidable physical damage associated to a disease, or even to death. Elvira's (seventy one years old, catholic) makes evident this circumstance: "Since my husband died everything has changed, because now I don't need to ask for permission to go to the church, I collaborate in a number of committees, I get along well with all people. I feel that they love me as much as I love them; we are busy visiting sick people, collecting food for needy people. I come here every day, what it was unthinkable then. In changing her role, whether by retiring from work, with the consequent lost of status, or due to her husband death, people resort to religious practices and beliefs, by playing other roles that allow them to keep the status achieved, providing them with identity and social reintegration.

Through faith, elders are able to make existential decisions, overcome their sufferings, providing themselves with the hope in a future life without suffering, in addition to construct meaning, selfesteem and security, happiness and optimism. ${ }^{7}$ Agustín (seventy four years old, evangelical): "It was due to an accident at sixty seven, that I felt motivated to look up and I start looking for God, to read the bible, my life acquired a new sense: I realized that being bedridden, chained to a wheelchair meant an opportunity for God to show me a new perspective, and above all the way to eternal life.

Guadalupe (seventy three years old, catholic), expresses: "Due to blindness I couldn't clean the house, cook my meals, going shopping, wash, iron. This makes me feel very sad, because I used to work hard; I always went here and there. Now I completely depend on somebody who helps me. In my darkest moments of my loneliness, I find refuge and consolation, speaking with Jesus. He gives me back faith and confidence that I'm not alone; he encourages me and gives me the

\footnotetext{
${ }^{6}$ Elder people build expectations from their belief in the divine agency. It is intriguing to see how in recent years, the universe of Saints, who reduce particular angst's and fears, has increased. Faced with angst, loneliness, disease, uncertainty, religion reinforces expectations in the guise of hope. Wishes translated into probabilities, which will not cause rupture, in case they are not accomplished. Religious practices and beliefs
}

Lead to a retrospective reflection in order to reconstruct life without any tragedy about future.

${ }^{7}$ If we check the catholic saint's calendar in our country, we find that the avocation of each Saint is specific to problems and sufferings. So, for example, San Judas Tadeo is assumed to be as the chief of the difficult cases; San Juan protects against rain, the virgin of Zapopan protects against the ray and spark, while Guízar specializes in difficult births, and so on. 
necessary strength to control my character, accept this situation, go ahead and don't give up, especially when there is somebody who helps me". As can be seen, religious practices and beliefs contributes welfare patterns in the middle of sufferance, as well as paradigms not only to endure, but also to change the incapacity attitude by a new perspective that involves reaching more control of life. The case of Cruz (sixty seven years old, catholic) is illustrative in this respect: "The cold weather causes my bones to swell and I can't rise up from my bed because of the arthritis, unless somebody helps me. I beg my little virgin $^{8}$ and Jesus' Sacred Heart strength, and little by little my bones improve. It's the spirit of God that gives me force." ${ }^{6,9}$ In the process of registering information, I noticed a great effort in Elder people to make evident and highlight the way in which the religious practices and beliefs help individuals to construct their welfare, since they meet in the bible narrative model the means to order their experiences, the way in which they should address their requests, to express their feelings and perceptions, justify their disability or dependency and make sense of their sufferance. ${ }^{10}$ These religious practices and beliefs are not only rites, chants, prayers, Reading the bible and to visit the church, but an experience they call: "an encounter with God"; it is a personal, intimate experience between God and the believer, which fills and vivifies.

\section{Results}

As we can see, to pay attention to the welfare construction is carried out in three moves: one inside, when God's gift is experienced in the tired, sick, exhausted body: especially in the heart and mind; when the believer feels provided with energy, inner peace harmony with himself, and, above all, with love. It is this latter movement which was more highly emphasized by our consultants. The second movement is outwards, "with the neighbor", when the whole spiritual arsenal that has been received is released: then, the needy are helped, the sick is visited, the person in troubles is advised, who does not have anything to eat is assisted, etc. It is usually in this second movement, where the degree of welfare experienced by the individual is displayed. The third move is upwards, with divinity, and it is consequence of the two previous moves. A spiritual dimension is reached, which connects the believer's spirit with God, by virtue of which any human difficulty is overcome: there is no fear to death, God is praised in spite of unhappiness; enjoyment and strength are experienced in spite of sadness or pain. It is here where consultants express the highest degree

\footnotetext{
${ }^{8}$ Referring to La Virgen of Guadalupe.

${ }^{9}$ Koenig6 showed that certain religious behaviors and attitudes indirectly contribute to the elder's health; as well as diet, hygiene practices and the avoidance of harmful behaviors. It reduces psychological stress; it prevents high pressure and some cardiovascular problems, and even avoids certain types of cancer. It makes evident that increasing religious participation or the return to it during old age, offers hope and emotional strength to some degree (higher than the obtained from other sources) to face such problems as health loss, Religion emphasizes the interpersonal relations, and stresses pardon not only to others, but also with oneself.

${ }^{10}$ In listening the testimony about how religious practices and beliefs work on the believers' life, Garma (1999) has noticed that the bible narrative model, constitutes a model according to which lived experiences are organized by the individual himself. In this way, experiences are ordered on the basis of life in sin, or life in ignorance, which carry as a consequence pain and sufferance; or contrarily, according to salvation, which involves pain relief, and suffering lessening. Taking this model as a reference, a discourse of his/her own life is constructed, with a social sense that makes it possible to explain the present, making coherent the pass, which in turn explains the past and projects future.
}

of welfare and happiness: "plenitude". Welfare is constructed this way; it is perceived as a plus in human life, as a personal and interpersonal transformation principle, ${ }^{7,11}$ being experienced a sense of plenitude, integrity and transcendence with oneself, with the others and with divinity. It is in this welfare feeling, that the believer articulates past experiences -not only of him/herself, but also of bible characters and virtuous believers- with his/her daily reality and projects him/herself into the future correlating and interconnecting his/her life meaning with his/her religious personal experience. In other words, the believer not only interconnects with other believers and share purposes and life meanings, but through religious practices and beliefs, Elder people is able to experience peace or joy in loneliness, anxiety, concern, feeling interconnected in a material world and in a supernatural one. In this welfare feeling a positive practice of integration, capacity and restoration is experienced, which finally release the tension caused by loneliness, abandonment, marginalization, etc ., while establishing a connection not only with alive ones, but also with those who are beyond, especially God, leaving aside or mitigating fears and giving continuity to welfare in the existence and in the beyond.

At this point, we need to keep in mind that the welfare feeling, although is not always real, it is actually accepted and adaptative. Elder showed a high degree of satisfaction with their life, as well as a higher awareness of their possibilities and limitations. Obviously, I founded information in the sense that non-compliance with religious practices and beliefs is the reason why sometimes a high degree of welfare is not obtained. For this reason is unavoidable to carry them out. The information makes it evident that in the hardest test, religious practices and beliefs acquired special meanings. It was under these circumstances that elder passed from the abstraction of a religious practice and belief to the practice of an action; amending, planning their strategies, controlling, enduring, adapting, allowing or avoiding that such a situation or need have a devastating effect. Interestingly, the fact that elder found in the bible narratives, experiences regarding widowhood, material, social and physical lost, sadness, accidents and sorrow, with which they identified themselves, and which only with the faith deposited in God, they were able to face. Appealing to them, gives them the sense of welfare, plenitude, hope, safety and divine protection, which mitigated their fair, heal them and helped them to meet their needs; it generated thoughts, attitudes and behaviors that helped them to incorporate limitations in a constructive manner and to accept the passage of time, even to accept death and what is beyond it. It produced a welfare that even science could not ever offer them.

This is why it is not surprising that the most loyal believer, happen to be elders, nor the fact that religiosity prevails in their daily life. These resources make it possible for them to face more easily the adversity of this life stage, an also to interpret, reinterpret, respond and adjust to the changing economic, political, and social circumstances of the time they have lived. ${ }^{12}$ Given these results I deemed indispensable to address welfare from the perspective of religious experiences, especially in a "society in risk" Giddens, ${ }^{8,13}$ where soul salvation is

${ }^{11}$ Religious practices and beliefs, as pointed out by Pittard,12 provide the believers with connection, integration and integrity.

${ }^{12}$ Regarding the differences we find between catholic and evangelicals, we can say that catholic' involvement and commitment is lower, which means that the satisfaction degree and welfare can be low in scale. In the case of evangelicals, on the other hand, we can find differences in the degree of welfare by virtue of his religious involvement and commitment.

${ }^{13}$ Giddens (1999), maintains that "living in a society at risk", which involves an attitude of visualizing new forms of action, favorable as well as 
closely related to material welfare. ${ }^{14}$ We need to keep in mind that living as an elder adult in a society where reasoning is given priority with respect to the development of religious practices and beliefs, could convey uncertainty and hopeless to elders, which makes difficult to give eld a sense. I agree with Daniel Bell, ${ }^{9,15}$ that the renaissance of religiosity is the only alternative to the current crisis.Faith, according to Bell, united to tradition will give as a result an individual with more clearly defined identities and existential security. ${ }^{16}$ Religion becomes necessary, as expressed by Geertz, ${ }^{10}$ "it establishes vigorous, penetrating and lasting animic states and motivations in men", by configurating a "general order of existence". ${ }^{10-15}$

\section{Conclusion}

Our research found that regardless of the situation of elderly people, age, sex, economic condition, social networks, etc., the possibility exists to live eld fully, experiencing happiness, satisfaction, love for life, searching a last meaning to everything we have been and experienced throughout our own existence, ${ }^{17}$ We need to take into account that hope and welfare during eld do not derive from biological, economic and social factors, but most times from the possibility to believe in a God, creator of everything that exists, who is the beginning and end. In spite of this human capability to believe becomes increasingly inhibited by modernity -which has constructed and reconstructed traditional systems of believing- fortunately has not empty believing. ${ }^{15-20}$

\section{Acknnowledgements}

None.

\section{Conflict of interest}

Author declares that there is no conflict of interest.

\section{References}

1. Masfarrer KE. Pluralidad religiosa en México. Cifras y proyecciones. Argentina: Editorial Araucaria; 2011.

unfavorable, we faced continuously, both individually and collectively. It is a society increasingly concerned with the future and safety, as a result of the modernization process itself, which affects the social organization

${ }^{14}$ It is worth noting that in the modernity it is not the individual who controls his uncertainties, nor God or the nature. It is now world of signs, symbols, and systems that only specialists can manage.

${ }^{15}$ Cited in Habermas (2008)

${ }^{16}$ Bell does not bet to the return of religiosity and the abandonment of modernity. On the contrary, he advocates for an understanding of religiosity not as a property of society, but rather a constitutive part of human consciousness: the cognitive search of the scheme of the general order of existence.

${ }^{17}$ Erikson expressed that the task in the last part of life is the fight between integrity and disappearance.
2. Amartya S. Desarrollo y Libertad. España: Editorial Planeta; 2000.

3. García BJC. Análisis del bienestar de los adultos mayores en México. Tesis de maestría en población y desarrollo. Sede México: En FLACSO; 2008.

4. Liberalesso NA. Bienestar subjetivo en la vida adulta y en la vejez. Hacia una psicología positiva en América latina. Revista Latinoamericana de psicología. 2002;34(1-2):55-74.

5. Elison GC. Religious Involvement and Subjective Well-Being. $J$ Health Soc Behav. 1991;32(1):80-99.

6. Sheldon ST, Elise MF, Gregory CS. Religiosity and fear of death in nonnormative aging. In: Eugene T, Susan A, editors. Aging and the religious dimension. Estados Unidos; 1994. p. 183-202.

7. Pittard PB. Susan HM. From loneliness to solicitude: Religious and spiritual journey in late life. In: Eugene T, Susan A, editors. Aging and the religious dimension. Estados Unidos; 1994. p. 13-28.

8. Giddens A. Riesgo y responsabilidad. Revisión moderna de la ley. 1999;62(1):1-10.

9. Habermas J, Baudrillard J. La Posmodernidad, Barcelona: Kairos, Editado por Hal Foster; 2008.

10. Geertz C. La interpretación de las culturas. México: Gedisa. 1995.

11. Carmona SE. El bienestar personal en el envejecimiento. IBEROFORUM. 2009;4(7):48-65.

12. Certeau DM. La debilidad de creer. Buenos Aires: Katz Editores; 2006.

13. Fábregas PA. El estudio antropológico de la religión. Religión y sociedad en el sureste de México. Ciesas: México; 1989. P. 3-21.

14. García H, Romeo M. Redes sociales y vejez: apoyos formales e informales en el área metropolitana de Monterrey. Papeles de Población, Nueva época. 1999;19(5):217-240.

15. Garma NC. Conversos, buscadores y apostatas. Estudio sobre la movilidad religiosa. In: Blancarte R, Casillas R, editors. Perspectivas del fenómeno religioso. México: FLACSO/Secretaría de Gobernación, 1999. p. 129-178.

16. Gómez VM. Calidad de vida. Instituto universitario de integración en la comunidad, universidad de Salamanca; 2001.

17. Palacios FV. El envejecimiento en México: el siguiente reto de la transición demográfica. Estudios fronterizos. 2003;5(9).

18. Johnson RT. The significance of religion for aging well. American behavioral scientist. 1995;39(2):186-202.

19. Abrham M. Motivación y personalidad. Ediciones Díaz de Santos. España: Freidenberg, Judith Noermi; 1991.

20. Vázquez FR. Diferenciaciones religiosas al final de la vida. Ponencia presentada en el evento una mirada antropológica de la vejez. México: Jalapa, Veracruz; 2006. 